\title{
Retrospective Analysis of Patients Treated for Volatile Substance Burn Injuries
}

\author{
Yücel Yüce, Banu Eler Çevik, Kutlu Hakan Erkal
}

Department of Anaesthesiology and Reanimation, Kartal Dr. Lütf Kırdar Training and Research Hospital, İstanbul, Turkey

Submitted: 11.01 .2018 Accepted: 24.01.2018

Correspondence: Yücel Yüce, Kartal Dr. Lütfi Kırdar Eğitim ve Araştırma Hastanesi, Anesteziyoloji ve Reanimasyon Kliniği, İstanbul, Turkey

E-mail: dryyuce@gmail.com

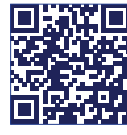

Keywords: Burns; intensive care; volatile substances.

\begin{abstract}
Objective: Volatile substance (VS) abuse has been defined as the use of chemical substances for non-medical purposes to achieve alterations in psychological functioning. Injury caused by VS abuse is an independent injury in and of itself; however, it is often combined with cutaneous burns, which are associated with increased morbidity and mortality. The aim of this study was to analyze the management of VS burn injuries referred to a burn center.
\end{abstract}

Methods: The records of 67 patients with VS burns who were hospitalized in a tertiary educating and training hospital burn center between July 2012 and July 2017 were analyzed in a retrospective study after receiving institutional ethical approval. The age, gender, injury type, and case management were retrospectively studied.

Results: All of the patients were young men, and most had a superficial burn injury. The length of stay in hospital ranged from 3 days to 22 days. In all, 8 patients (1 I.9\%) were followed-up in the burn intensive care unit. All of the patients were treated with conservative management, and there was no mortality.

Conclusion: Preventing the abuse of inhalants can prevent the occurrence of this type of burn. The development and evaluation of strategies for the treatment of chronic abusers and for the prevention of inhalant use are major challenges for the future.

\section{INTRODUCTION}

A burn injury is a highly varied and individual health problem that occurs in all ages and in all countries. ${ }^{[1]}$ Burns are the fourth most common type of trauma worldwide, following traffic accidents, falls, and interpersonal violence, and they represent a significant public health concern. ${ }^{[2]}$ Death due to burn injury is most common in developing countries; it is estimated to be II times higher than in high-income countries. The treatment of burn injuries should include a multidisciplinary approach with experienced burn physicians and healthcare workers in a wellequipped burn unit or center. ${ }^{[3]}$ Flame burns, scalds, and contact burns are the top 3 types of severe burns in most studies. ${ }^{[4,5]}$

Volatile solvents (VS) are now used commonly worldwide in fuels, paints, and thinners, which are then used in a variety of industrial applications in daily life. These compounds are also often intentionally inhaled at high concentrations to produce intoxication. VS are widely available in stores without any legal restriction. ${ }^{[6]}$ VS abuse can be observed everywhere in the world, but it is more commonly observed in countries with a lower socioeconomic level..$^{[7,8]}$

The liquid petroleum gas in cigarette lighters is typically butane gas. It is a gas used as a propellant in aerosols and as combustible fuel in stoves and cigarette lighters. It is frequently abused as a narcotic through inhalation. It can cause flame burns when present at high concentrations in the medium and when it comes in contact with combustible agents. ${ }^{[9]}$

This study is a retrospective assessment of patients with VS burns who were treated in a tertiary burn center in Istanbul, Turkey.

\section{MATERIAL AND METHODS}

This was a retrospective, descriptive, hospital-based study, using data from 2012 to 2017 . The study was approved by 
the Kartal Dr. Lutfi Kirdar Research and Training Hospital review board and ethics committee. The records of all 67 VS burn patients admitted to the tertiary hospital burn unit between July 2012 and July 2017 were reviewed. All of the patients were between 13 and 27 years of age. No VS patient was excluded from the study. The patients' charts and Burn Intensive Care Unit (BICU) documentation log were reviewed.

This burn center is well equipped, and has a multidisciplinary staff consisting of general surgeons, plastic surgeons, anesthetists in the BICU and operating rooms, infectious disease doctors, pediatric surgeons, physiotherapists, psychologists, dieticians, and burn nurses, according to the American Burn Association (ABA) criteria. It has a helicopter landing field and accepts patients from every region of the country. It has $6 \mathrm{BICU}$ rooms, 16 burn service beds, and 2 separate operating rooms all housed in one building. All $6 \mathrm{BICU}$ rooms were designed according to the ABA criteria, with high efficiency particulate air (HEPA) filters, laminar air flow, and separated beds.

The age and gender of the patient, the depth of the burn injury, the total body surface area (TBSA) and the distribution of the burn area according to the ABA criteria, the infection foci, unusual microorganism growth in cultures, and the treatment were analyzed.

IBM SPSS Statistics for Windows, Version 20.0 (IBM Corp., Armonk, NY, USA) was used to analyze the data. The numerical variables were expressed as mean $\pm S D$. The patient demographic data and outcomes were assessed for normality and parametric or nonparametric tests were performed, as appropriate. The Mann Whitney U-test test was used to compare continuous variables and a chisquare test was used to compare categorical variables. A p value of $<0.05$ was considered statistically significant.

This study was performed according to the principles of the Helsinki Declaration.

\section{RESULTS}

During the study period, a total of 2413 burn patients were hospitalized; $58 \mathrm{I}$ of them in the BICU and 1764 of them in the burn service. In this 5-year period, a total of 67 VS burn patients were admitted to the burn center.

The mean age of the VS burn patients was 16.7 years, with a range of 13 to 27 years. All of the patients were male (Fig. I).

In this study, 67 patients (100\%) were burned while smoking cigarettes, and there was direct combustion of the cigarette lighter in 44 cases (65.7\%). In 7 cases there was ignition although there was no combustible material in the medium. All of the burn injuries were localized on the upper extremities or face.
In total, II patients (16.4\%) were treated in the emergency burn room and 48 patients $(71.7 \%)$ were followedup in the burn service. Eight patients (11.9\%) were admitted to the BICU.

The mean TBSA of the study patients was $8.8 \%$ (range: 2-54\%) (Fig. 2). In 44 patients (65.7\%) the burn depth was at the dermal level, and in 23 patients (34.3\%), mixed full thickness burns were observed.

The mean body surface burn percentage was $17.16 \pm 1.75 \%$.

Eight patients were assessed as having a major burn, 26 cases were classified as moderate, and 33 were minor. All of the patients sustained facial burns (100\%) and $83.6 \%$ also presented with burns on the hands. In $75.7 \%$ of the cases, the burn was evaluated as grade III, and $24.3 \%$ were grade II.

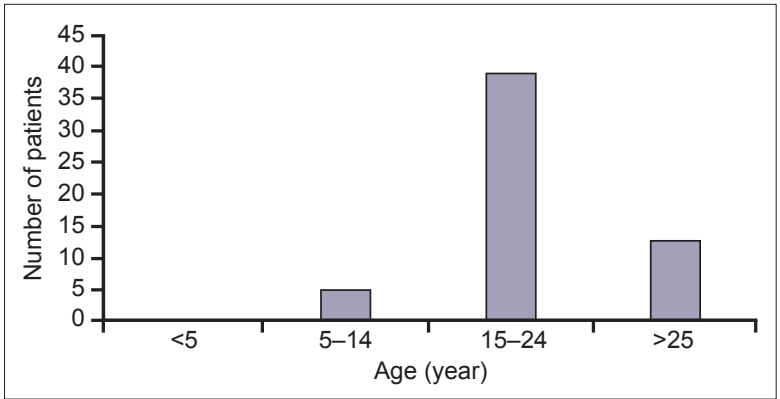

Figure 1. Age distribution of the patients referred to the burn center.

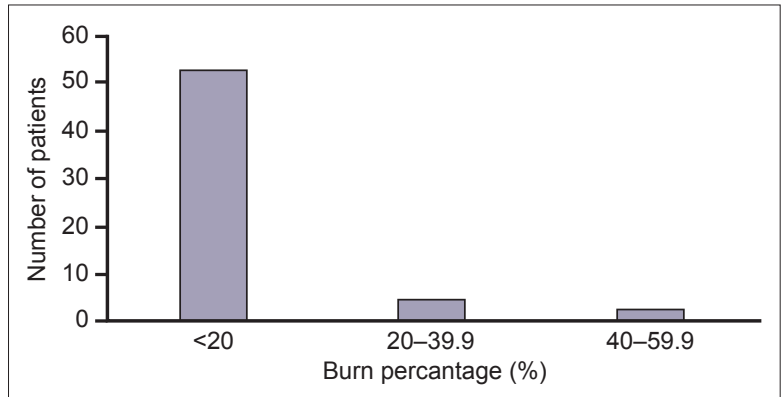

Figure 2. Distribution of the total body surface area burned.

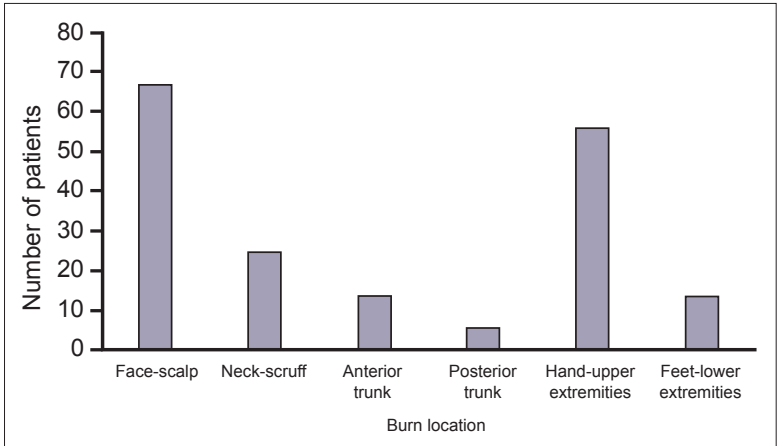

Figure 3. Distribution of the locations of the burns among the patients. 
The duration of hospitalization in this study ranged from 3 days to 22 days, with a mean length of hospital stay of 11.8 days. Eight of the patients were in the ICU for 9.1 days (range: 5-24 days).

In all, 5 I (76.l\%) of the patients acknowledged previous inhalation of VS. The remaining 16 cases $(23.9 \%)$ were reported by their parents. In 15 cases, there had been an earlier diagnosis of substance abuse.

The patients were examined and treated according to the ABA criteria. A total of 44 patients $(65.7 \%)$ were treated only by dressing the injury with burn products. In 20 cases (29.8\%), a split-thickness skin graft was applied. Tarsorrhaphy was performed on 3 patients (4.5\%) to prevent contraction of the upper and lower eyelids. No amputation or flap intervention was performed. Respiratory physiotherapy and physiotherapy for all extremities were applied during the service follow-up. Custom pressure garments and silicone gel sheets were used during the postoperative period. Joint mobility and esthetic appearance were excellent at 3-month and 6-month follow-up examinations of the patients.

Overall, the injuries were described as a dermal burn in 44 patients (65.7\%) and full thickness burns in 23 patients (34.3\%). Eight patients sustained major burns, 26 were moderate, and 33 were minor burns.

Burns from an open flame $(n=67 ; 100 \%)$ were the most common type of burn. Sixty-seven patients (100\%) had facial burns and the majority of patients (6I patients; $91.0 \%$ ) presented with more than I burn site (Fig. 3).

There was no instance of mortality in the study patients.

\section{DISCUSSION}

Among trauma patients, burn injuries can be defined as one of the more severe pathologies since they can result in significant morbidity and mortality. The treatment of burn injuries, whether in surgery clinics or intensive care units, can be a lengthy and very expensive process of wound treatment and rehabilitation. ${ }^{[10]}$

The prevalence and mortality rate of burns varies significantly between countries. One study reported the annual instance as II2-518/100,000. ${ }^{[1]}$

Epidemiological factors in burn injuries also vary between communities and regions of the world. ${ }^{[1]}$ The most common types of burns in all age groups are flame burns and scalds. ${ }^{[2,13]}$ Explosion burns that occurred during inhalation of VS have also been reported in the literature. ${ }^{[14]}$

When the types of burns are examined with according to gender, it has been reported that men are more likely to have flame burns, while there is a higher proportion of scalds and contact burns among women. ${ }^{[14]}$ Our study also demonstrated a high ratio of flame burns in young males
(Fig. 4a). The gender distribution of our patients is consistent with the literature.

VS abuse has been defined as the use of chemical substances for non-medical purposes to achieve alterations in psychological functioning. VSs have widespread availability, they are inexpensive, legally sold in packaging suitable for use, and rapidly induce euphoria. ${ }^{[14]}$ As substances of abuse, the vapors of these chemicals are intentionally inhaled to produce psychoactive effects. These are classified into 4 broad groups: volatile solvents (e.g., typewriter correction fluid, typewriter diluent fluid, glue, paint thinner and gasoline), aerosols (e.g., hair spray and spray paint), gases (e.g., nitrous oxide and ether) and nitrites (such as amyl-, butyl-, and isobutylnitrites). ${ }^{[14]}$

The method of delivery is inhalation of a VS, typically from its container, through a soaked rag, or using a bag. Aerosols and some sprays can be expressed directly into the mouth or nose. ${ }^{[14,15]}$ Exposure to a VS can affect multiple organs, such as the central nervous system, myocardium, liver, spleen, and kidneys. The gas leaves the body via exhalation. Abusers often begin to increase the frequency and duration of inhalant abuse to extend the effects. Inhalant misuse is increasing because abusers can find the items easily, they are low-cost, and they are legal. In our series, the most commonly abused substances leading to burn injuries were propane, glue, and paint. The most widely used inhalants in Turkey are paint thinners and glues. The most commonly abused substances reported to US poison control centers from 1996 to 200 I were gasoline (4I\%), paint (13\%), propane/butane (6\%), air fresheners (6\%), and formaline (5\%). ${ }^{[16,17]}$

Most of the burn cases (6I.I\%) occurred while smoking cigarettes. In an enclosed space, vapor becomes extremely flammable and explosive when an ignition source is introduced, whether it be a flame or a spark. The use of a VS in an enclosed space can cause comprehensive injuries (3 cases). We believe that sensory defects in these patients may prevent their detection of the burns and lead to injuries of greater severity.

Gender is an important epidemiological determinant of burn injury. Our results identify young males as at particular risk for VS burns. VS abuse is a problem that is gaining
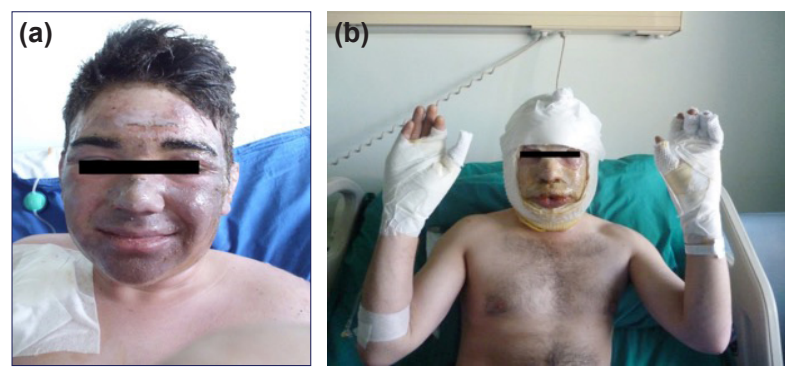

Figure 4. (a) Facial burn. (b) Burns on the face and hands 
importance in children and young adults. VS use is more common among male adolescents, and abuse also begins very early in Turkey. ${ }^{[18]}$ The mean age of our VS burn patient population was 16.7 years, and our oldest patient was 27 years of age. Our observations were consistent with the statistics.

The burn injuries were described as a dermal burn in 44 patients $(65.7 \%)$ and full thickness burns in 23 patients (34.3\%). Eight patients sustained major burns, 26 patients had burns that were classified as moderate, and 33 patients had minor burns.

All of the patients in the study received the burns from an open flame $(n=67 ; 100 \%)$. All of the patients sustained facial burns and the majority of patients (6I patients; $91.0 \%$ ) presented with more than I burn site (Figs. 3 and 4b). These are typical anatomical locations of VS burns. ${ }^{[18]}$

The percentage (TBSA) burned in the patients evaluated ranged from $2 \%$ to $54 \%$. The mean TBSA was $8.8 \%$. The $\%$ TBSA in male acid burn patients was $14.47 \pm 11.56 \%$ in male patients and $20.00 \pm 16.49 \%$ in female patients. ${ }^{[19]}$

Burns are classified and treated according to new ABA criteria. We observed burns on the face in all of the study patients. Facial burns are generally considered severe due to the possibility of respiratory complications. ${ }^{[20]}$ The percentage varies between $27 \%$ and $60 \%$, depending on the country, setting, and definition of what constitutes a facial burn. ${ }^{[20-22]}$ Because of the difficulty and complexity of wound care, including pain and the frequent cleansing needed to avoid infection, partial thickness burns on the face often require hospital care. ${ }^{[22]}$ Facial burns are often flash burns, which usually result in partial thickness burns.

The mean duration of hospitalization in our study was II.8 days. We believe that this short duration was due to the relatively mild average degree of the burns in our patient population. Eight of the patients were followed-up in the BICU for a mean of 9.I days (range: 4-24 days). The reasons for BICU follow-up were facial edema and airway safety. None of the patients in this study required mechanical ventilation, as there was no respiratory deficiency.

The mortality rate has a significant relationship to the TBSA, and it has been calculated as between $1.4 \%$ and $34 \%$ in different populations. ${ }^{[12,13]}$ A TBSA of $>40 \%$ in adults and $>60 \%$ in children is accepted as indicating a higher risk of mortality and morbidity independent of the technical setting of the burn center. ${ }^{[14]}$ In our study, the mean burned TBSA was $8.8 \%$ and we observed no mortality (0\%).

\section{Conclusion}

Burn trauma is a major public health problem requiring lengthy hospitalization in both ICUs and general wards. Many studies report that $>20 \%$ of the admitted patients die in the hospital.
VS abuse is a worldwide problem that has been recognized as a potential drug problem for many years. The development and evaluation of strategies for the treatment of chronic VS abusers and for the prevention of VS abuse are major challenges for the future. Burns related to gas explosions need special attention as result of thermal trauma as well as possible associated psychopathological problems of the abusers.

\section{Ethics Committee Approval}

Approval has been obtained from the Kartal Dr. Lütfi Kırdar Training and Research Hospital Ethics Committee.

\section{Informed Consent}

Retrospective study.

Peer-review

Internally peer-reviewed.

Authorship Contributions

Concept: Y.Y., B.E.Ç., K.H.E.; Design: Y.Y., B.E.Ç., K.H.E.; Data collection \&/or processing: Y.Y., K.H.E.; Analysis and/ or interpretation: Y.Y., B.E.Ç., K.H.E.; Literature search: Y.Y., K.H.E.; Writing: Y.Y., K.H.E.; Critical review: Y.Y., B.E.Ç., K.H.E.

\section{Conflict of Interest}

None declared.

\section{REFERENCES}

1. Thorne $\mathrm{CH}$, Chung KC, Gosain AK. Grabb and Smith's Plastic Surgery. 7th ed: Philadelphia: Lippincott Williams \& Wilkins: 2014.

2. Hashmi M, Kamal R. Management of patients in a dedicated burns intensive care unit (BICU) in a developing country. Burns 2013;39:493-500. [CrossRef]

3. Anderson CE, Loomis GA. Recognition and prevention of inhalant abuse. Am Fam Physician 2003;68:869-74.

4. Busche MN, Gohritz A, Seifert S, Herold C, Ipaktchi R, Knobloch $\mathrm{K}$, et al. Trauma mechanisms, patterns of injury, and outcomes in a retrospective study of 71 burns from civil gas explosions. J Trauma 2010;69:928-33. [CrossRef]

5. Haik J, Liran A, Tessone A, Givon A, Orenstein A, Peleg K; Israeli Trauma Group. Burns in Israel: demographic, etiologic and clinical trends, 1997-2003. Isr Med Assoc J 2007;9:659-62.

6. Kaddoura I, Abu-Sittah G, Ibrahim A, Karamanoukian R, Papazian N. Burn injury: review of pathophysiology and therapeutic modalities in major burns. Ann Burns Fire Disasters 2017;30:95-102.

7. Song C, Chua A. Epidemiology of burn injuries in Singapore from 1997 to 2003. Burns 2005;31 Suppl 1:S18-26. [CrossRef]

8. Lau YS. An insight into burns in a developing country: a Sri Lankan experience. Public Health 2006;120:958-65. [CrossRef]

9. Peck MD, Kruger GE, van der Merwe AE, Godakumbura W, Ahuja RB. Burns and fires from non-electric domestic appliances in low and middle income countries Part I. The scope of the problem. Burns 2008;34:303-11. [CrossRef]

10. Oh SJ, Lee SE, Burm JS, Chung CH, Lee JW, Chang YC, et al. Explosive burns during abusive inhalation of butane gas. Burns 
1999;25:341-4. [CrossRef]

11. Brusselaers N, Monstrey S, Vogelaers D, Hoste E, Blot S. Severe burn injury in Europe: a systematic review of the incidence, etiology, morbidity, and mortality. Crit Care 2010;14:R188. [CrossRef]

12. Othman N, Kendrick D. Epidemiology of burn injuries in the East Mediterranean Region: a systematic review. BMC Public Health 2010;10:83. [CrossRef]

13. Tompkins RG, Liang MH, Lee AF, Kazis LE; Multi-Center Benchmarking Study Working Group. The American Burn Association/ Shriners Hospitals for Children Burn Outcomes Program: a progress report at 15 years. J Trauma Acute Care Surg 2012;73:S173-8.

14. Nakawaki B, Crano W. Patterns of substance use, delinquency, and risk factors among adolescent inhalant users. Subst Use Misuse 2015;50:114-22. [CrossRef]

15. Snell JA, Loh NH, Mahambrey T, Shokrollahi K. Clinical review: the critical care management of the burn patient. Crit Care 2013;17:241.

16. Medina-Mora ME, Real T. Epidemiology of inhalant use. Curr Opin Psychiatry 2008;21:247-51. [CrossRef]
17. Jeschke MG, Pinto R, Kraft R, Nathens AB, Finnerty CC, Gamelli $\mathrm{RL}$, et al; nflammation and the Host Response to Injury Collaborative Research Program. Morbidity and survival probability in burn patients in modern burn care. Crit Care Med 2015;43:808-15. [CrossRef]

18. Büker HS, Demir E, Yüncü Z, Gülen F, Midyat L, Tanaç R. Effects of volatile substance abuse on the respiratory system in adolescents. Multidiscip Respir Med 2011;6:161-8. [CrossRef]

19. Anlatici R, Ozerdem OR, Dalay C, Kesiktaş E, Acartürk S, Seydaoğlu G. A retrospective analysis of 1083 Turkish patients with serious burns. Part 2: burn care, survival and mortality. Burns 2002;28:239-43. [CrossRef]

20. Klein MB, Hayden D, Elson C, Nathens AB, Gamelli RL, Gibran NS, et al. The association between fluid administration and outcome following major burn: a multicenter study. Ann Surg 2007;245:622-8.

21. Ahuja RB, Bhattacharya S. Burns in the developing world and burn disasters. BMJ 2004;329:447-9. [CrossRef]

22. Muller MJ, Pegg SP, Rule MR. Determinants of death following burn injury. Br J Surg 2001;88:583-7. [CrossRef]

\section{Yanık Merkezimizde Tedavi Edilmiş Uçucu Madde Yanı̆̆ı Olan Hastaların Geriye Dönük Analizi}

Amaç: Uçucu madde bağımlılığı, kimyasal maddelerin psikolojik fonksiyonlarda değişikliklere ulaşmak için tıbbi olmayan amaçlarla kullanımı şeklinde tanımlanmıştır. Uçucu maddelerle oluşan hasar tek başına bağımsız bir hasar olabileceği gibi; sıklıkla yüksek morbidite ve mortaliteye sahip kütanöz yanıklarla da ilişkili olabilir. Bu çalışmada, yanık merkezimize yönlendirilmiş uçucu madde yanık hasarlarının yönetimini rapor etmeyi amaçladık.

Gereç ve Yöntem: Temmuz 2012-Temmuz 2017 tarihleri arasında bir 3. basamak eğitim ve araştırma hastanesi yanık merkezinde tedavi edilmiş uçucu madde yanığı olan 67 hasta bir geriye dönük çalışmada analiz edildi. Yaş, cinsiyet, hasar tipi ve tedavi yöntemleri geriye dönük olarak incelendi.

Bulgular: Hastaların tümü genç erkeklerdi ve çoğunda yüzeysel yanık hasarları vardı. Hastanede kalış süresi 3-22 gündü. Sekiz hasta (\% I .9) yanık yoğun bakım ünitesinde takip edildi. Hastaların tümü konservatif yöntemlerle tedavi edildi ve mortalite oranı sıfırdı.

Sonuç: Uçucu maddelerin suistimalinin önlenmesi bunlara bağlı yanık hasarlarının oluşmasını da önleyecektir. Kronik kullanıcıların tedavilerine yönelik tedavi stratejilerinin geliştirilmesi ve değerlendirilmesi ile uçucu madde kullanımının önlenmesi gelecek için temel kavramlar olacaktır.

Anahtar Sözcükler: Uçucu maddeler; yanıklar; yoğun bakım. 